U.S. Department of the Interior

U.S. Geological Survey

\section{Estimated Water Use at Dairy Farms in Gooding, Jerome, and Twin Falls Counties, Idaho, 1990-93}

\section{Introduction}

From 1890 to 1990 , the dairy cow population in Idaho increased from 24,000 to 170,000 , excluding heifers, calves, and bulls; a little more than one-third of the population was in Gooding, Jerome, and Twin Falls Counties. Dairy farms in the three counties accommodate Idaho's greatest number of dairy cows (Idaho Agricultural Statistics Service, 1994) (fig. 1). Idaho was ranked thirteenth nationally for milk production during 1990 and was ranked eleventh in 1993. In 1993, Idaho produced 208 million pounds of American cheese and was ranked fourth nationally in American cheese production. Coincidentally, one of the largest cheese processing plants in the Nation opened in Jerome County in the same year.

Dairy farms use water for two purposes: drinking water for cows, and facility operations such as washing, sanitation, and other uses. Drinking water is the largest water use on dairy farms. Ground water is the primary source of supply, although some dairy farms use supplemental surface-water resources. In this report, ground water is assumed to be the sole source of supply.

\section{Data Sources}

Population data for dairy cows were collected from several sources and used to estimate the total water use for each county. The Idaho Agricultural Statistics Service (IASS) of the Idaho Department of Agriculture reports annual estimates for all types of cattle. The estimates for cattle were subdivided into listings for beef cows, dairy cows, and other cattle (Idaho Agricultural Statistics Service, 1994). Beef cow populations were not used. Other cattle (defined as calves, bulls, steers, and heifers) also were not used because dairy heifers and calves could not be differentiated from beef heifers and calves. Only the population of dairy cows that have calved were used from this data source.
Every 5 years the U.S. Bureau of Census conducts a census of agriculture; the last one was in 1992. The dairy cow population data from the census were compared to the IASS extimates for each county to establish a relation between the two (table 1). IASS estimates were used to calculate water use because data were available for each year during 1990-93, whereas only 1992 census data related to this study.

The IASS dairy cow population estimate was about 20 percent lower than the census data for Gooding County and about 1.5 percent higher than the census data for Jerome County. The IASS estimate for Twin Falls County was about 10 percent smaller than the census data for that county. For this study, no corrections were made to the IASS estimates using the 1992 census data.

Dairy cow and facility water-use coefficients were provided by Robert M. Ohlensehlen, University of Idaho, Cooperative Extension Service, Twin Falls County. The number of dairy farms per county, herd sizes, and other pertinent information was provided by Marv Patten, Idaho Department of Agriculture. This information was used extensively to differentiate the types of dairy cows and to estimate water use for drinking water and facility operations.

\section{Estimation Methods}

Estimates of drinking water use for each county were calculated from dairy cow populations and seasonal per capita use coefficients. Estimates for facility water use were calculated from average water-use coefficients and population data.

There are three types of dairy cows-lactating, dry, and replacement. Each type of cow composes a different proportion of a typical dairy farm herd and has a different water-use coefficient. Replacement cows are younger than 24 months and are reared to replace the aging cows of the lactating herd. Typically, 83 percent of the herd are lactating cows and 17 percent are dry

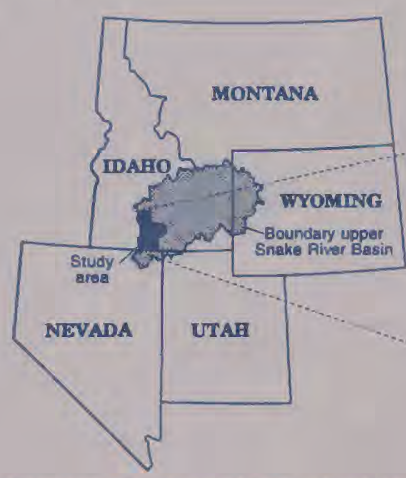

Figure 1. Location of study area.

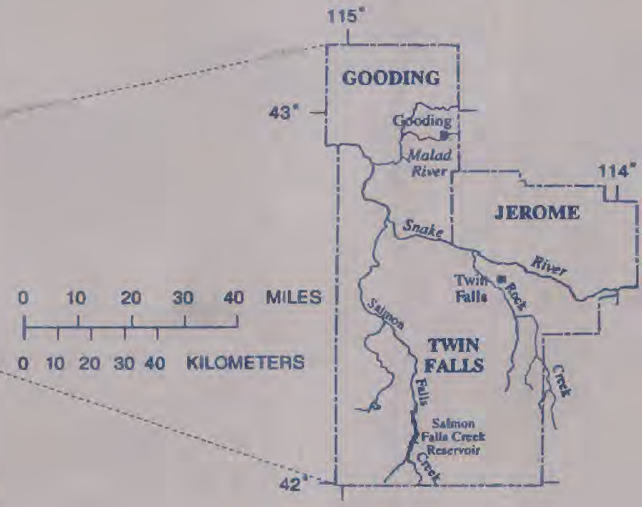

cows. Ideally, a replacement cow exists for every dry or lactating cow.

Lactating and dry cow populations were estimated using the typical herd percentages and 1990-93 IASS dairy cow populations. Replacement cow populations were presumed to be equal to the lactating cow populations. Replacement cow populations were subdivided further according to age: 0-12 months, 50 percent; $13-16$ months, 12 percent; and 17-24 months, 38 percent (Robert Ohlensehlen, University of Idaho, Cooperative Extension Service, oral commun., 1994). These subdivisions were made because replacement cows of different ages consume different quantities of water.

Drinking water estimates were made using population data and seasonal per capita use coefficients that are unique to each type of cow. High and low water-use seasons were determined using monthly milk production records (Idaho Agricultural Statistics Service, 1994). May through August is the high-use season and September through April is the low-use season. Per capita use coefficients for lactating cows are about 46 gallons per day (gal/d) during the highuse season and $22 \mathrm{gal} / \mathrm{d}$ during the low-use season. The coefficients for dry cows are about 16 $\mathrm{gal} / \mathrm{d}$ and almost $10 \mathrm{gal} / \mathrm{d}$ during the high-use and the low-use seasons, respectively (Robert Ohlensehlen, University of Idaho, Cooperative Extension Service, oral commun., 1994). The coefficients for replacement cows are about 10 $\mathrm{gal} / \mathrm{d}$ during the high-use season and $6 \mathrm{gal} / \mathrm{d}$ during the low-use season.

Facility water-use estimates were calculated using only lactating cow populations and a wateruse coefficient for a typical large herd (greater than 300 head) at an average usage of $6,356 \mathrm{gal}-$ lons per cow per year (Robert Ohlensehlen, University of Idaho, Cooperative Extension Service, oral commun., 1994). Dry and replacement cow populations were omitted from facility water-use estimates because those cows would not ordinarily be in the milking barns and, therefore, would not affect the amount of water used.

Table 1. Comparison between 1992 U.S. Bureau of Census (Census) data and Idaho Agricultural Statistics Service (IASS) dairy cattle population data

\begin{tabular}{|c|c|c|}
\hline Counties & Census & IASS \\
\hline Gooding ... & 32,481 & 26,000 \\
\hline Jerome.............. & 32,041 & 32,500 \\
\hline 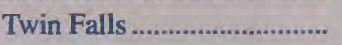 & 18,301 & 16,500 \\
\hline
\end{tabular}




\section{Water Use}

During 1990-93, dairy cow populations, including estimated replacement cow populations, increased more than 37 percent in the three counties (fig. 2)-from 113,000 to almost 155,000 . During the 4 years, the dairy cow population increased 50 percent in Twin Falls County, 41 percent in Gooding County, and 26 percent in Jerome County.

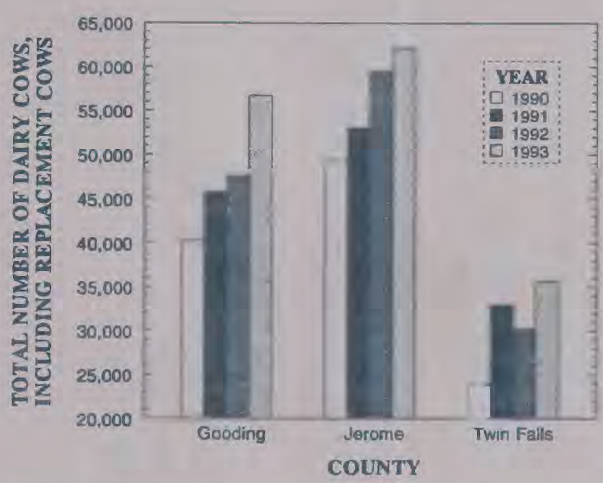

Figure 2. Total number of dairy cows in Gooding, Jerome, and Twin Falls Counties during 1990-93.

Not all dairy farms raised replacement cows. Dairy farms in some counties raised more replacement cows than they needed and, thus, were suppliers for other counties. In 1993, 79 percent of farms in Gooding County, 82 percent of farms in Jerome County, and 65 percent of farms in Twin Falls County raised replacement cows. Because estimates for replacement cow populations were based on the assumption that a replacement cow exists for every dry or lactating cow, drinking water values were probably overestimated for Twin Falls County. Facility wateruse estimates were unaffected because replacement cow populations were not used in those estimates.

In 1993, Gooding County had 132 dairy farms: 37 percent of the farms had herds of more than 250 cows. Twin Falls County had 98 dairy farms,

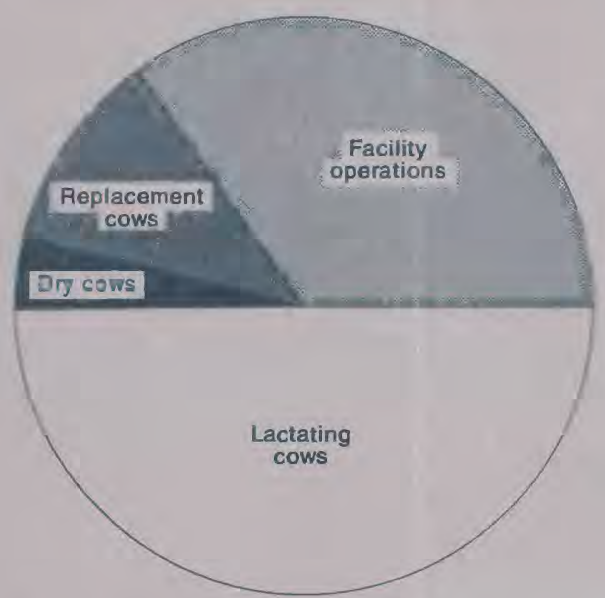

Figure 3. Average annual water used for cattle and facility operations, 1990-93. but only 30 percent of the farms were considered large-herd dairies. Although Jerome County had only 78 dairy farms, that county had 58 percent large-herd dairies (Marv Patten, Idaho Department of Agriculture, Dairying Bureau, oral commun., 1994). In Jerome County, a high percentage of large-herd dairies probably raised replacement cows. Twin Falls County had many smallherd dairies and few raised replacement cows.

More water was used for lactating cows than was used for facility operations. In fact, the total average annual water use during $1990-93$ for lactating cows was nearly equal to all other dairy water uses combined (fig. 3). Lactating cows used about 660 million gallons per year (Mgal/yr) and facility operations used about $460 \mathrm{Mgal} / \mathrm{yr}$. Re-placement and dry cows used about 150 and $50 \mathrm{Mgal} / \mathrm{yr}$, respectively. Even though re-placement cows drink less water than dry cows, replacement cows theoretically compose a large part of a herd. More than 50 percent of the drinking water and more than 95 percent of the facility operations water was used during the highly productive months of May through August.

The relations between different types of dairy cows and drinking water use during 1990-93 are shown in figure 4. Most water was used in Jerome County because of the higher percentage of large-herd dairies. Water use in Gooding County in-creased steadily during 1990-92 and greatly increased between 1992 and 1993. More water was used in Twin Falls County in 1991 than in 1990; water use decreased slightly in 1992 but recovered and was highest in 1993.

In Idaho, more than 95 percent of total water use is for irrigation. In Jerome, Gooding, and Twin Falls Counties, some lands that were used for growing crops have been converted to dairy farms. A comparison between the amount of water used on a dairy farm and the amount of

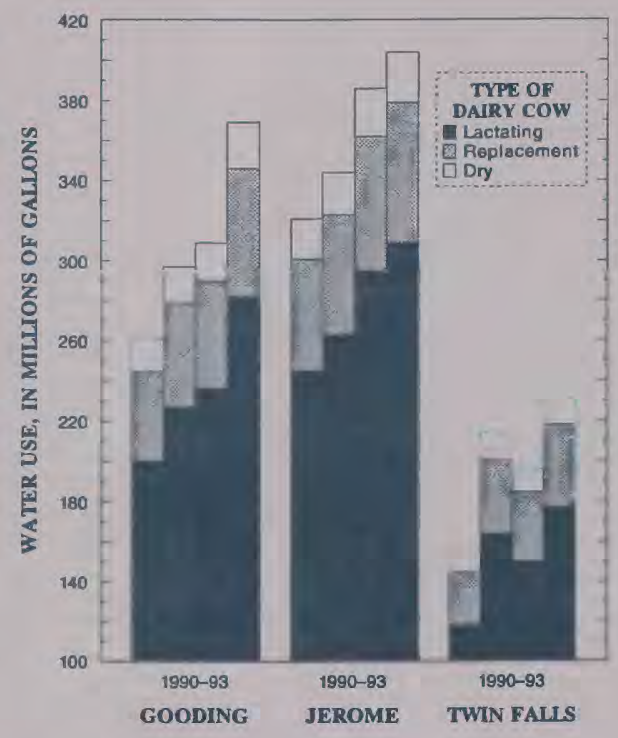

Figure 4. Water use for different types of dairy cows in Gooding, Jerome, and Twin Falls Counties during 1990-93. water used to irrigate a potato crop showed that irrigation used much more water than a dairy farm. A typical 1,000-head dairy farm situated on about 40 acres would use about 50 acre-feet of water per year. An acre of potatoes near Twin Falls would require 21 inches of irrigation water to supplement precipitation (Sutter and Corey, 1970). Pumps and irrigation equipment are generally less than 75-percent efficient; therefore, 40 acres of potatoes would need about 93 acre-feet per year of water to grow. A dairy farm would take almost 2 years to use the same amount of water. A comparison of water used on dairies and water used to irrigate several crop types is shown in figure 5.

-Molly Maupin

\section{References}

Idaho Agricultural Statistics Service, 1994, Idaho agricultural statistics: Boise, Department of Agriculture and National Agricultural Statistics Service, 72 p.

Idaho Department of Health and Welfare, 1993, Idaho waste management guidelines for confined feeding operations: Twin Falls, Idaho Department of Health and Welfare, Division of Environmental Quality, 82 p.

Sutter, R.J., and Corey, G.L, 1970, Consumptive irrigation requirements for crops in Idaho: Moscow, University of Idaho, 97 p.

U.S. Bureau of Census, 1994, United States summary and State data, 1992 census of agriculture, geographic area series, v. I, part 51: U.S. Bureau of Census, Special Report Series AC 92-A-51, 309 p., including apps.

\section{For more information contact:}

U.S. Geological Survey

230 Collins Road

Boise, ID $83702-4520$

(208) $387-1300$

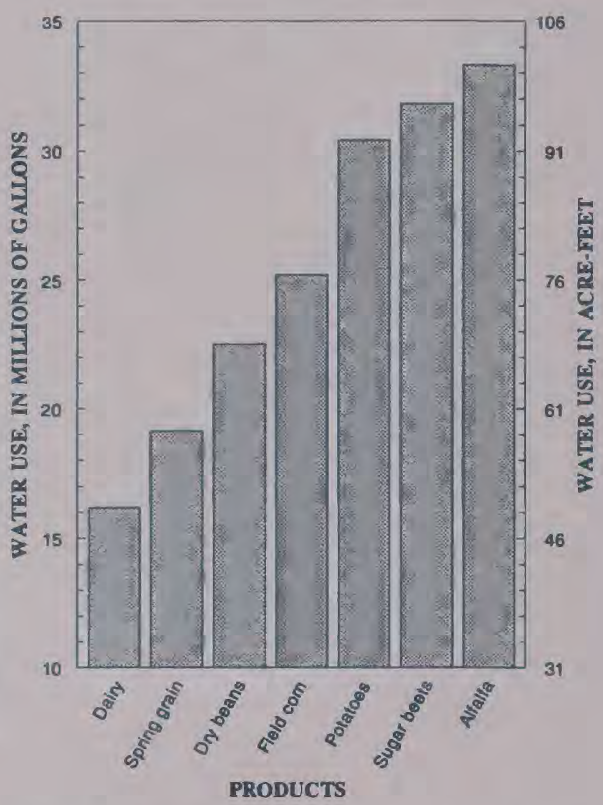

Figure 5. Total water used on dairies and total water used to irrigate several crop types. 